\title{
Sistem Informasi Ekstrakurikuler Berbasis Website Menggunakan System Development Life Cycle (SDLC) Pada SMAN 16 Gowa
}

\author{
Ayu Lestari Perdana*1, Suharni ${ }^{2}$ \\ ${ }^{1,2}$ Program Studi Teknik Informatika, Fakultas Teknik, \\ Universitas Islam Makassar, Indonesia \\ Email: ' ayulestariperdana.dty@uim-makassar.ac.id, 2suharni.dty@uim-makassar.ac.id
}

\begin{abstract}
Abstrak
Perkembangan teknologi dalam dunia pendidikan sangat penting dalam membangun manusia Indonesia seutuhnya. Penelitian ini bertujuan untuk mengevaluasi sistem informasi sekolah pada kegiatan organisasi ekstrakurikuler di SMAN 16 Gowa. Pengelolaan anggota organisasi di sekolah yang sebelumnya menggunakan pencatatan manual menjadi komputerisasi berbasis web. Metode yang digunakan dalam penelitian ini adalah System Development Life Cycle (SDLC) yaitu metodologi klasik yang digunakan untuk mengembangkan, memelihara dan menggunakan sistem informasi. Adapun tahapan-tahapan System Development Life Cycle (SDLC) yaitu perencanaan sistem, analisis sistem, desain sistem, Implementasi sistem serta operasi dan pemeliharaan. Hasil penelitian menunjukkan bahwa Website ekstrakurikuler pada SMAN 16 Gowa menjadi sumber informasi ekstrakurikuler, memberikan informasi mengenai jumlah siswa yang mengikuti ekstrakurikuler, jadwal maupun kegiatan ekstrakurikuler dan media pendaftaran ekstrakurikuler sehingga siswa mampu mendaftar secara online tanpa harus registrasi secara langsung. Fitur-fitur yang dimiliki yaitu jadwal kegiatan ekstrakurikuler, prestasi ekstrakurikuler, galeri ekstrakurikuler dan fitur chat dengan ketua ekstrakurikuler. Sistem Informasi yang dibangun ini mempermudah dalam penginputan dan sesuai dengan sistem yang diusulkan. Pengujian dan implementasi sistem ini sesuai dengan hasil yang diharapkan dimana fungsional input dan output sistem berfungsi dengan baik untuk menggantikan sistem manual yang selama ini digunakan.
\end{abstract}

Kata kunci: Ekstrakurikuler, Sistem Informasi, SMAN 16 Gowa, System Development Life Cycle (SDLC)

\section{Website Based Information System of Extracurricular Uses the System Development Life Cycle (SDLC) at SMAN 16 Gowa}

\begin{abstract}
The development of technology in the world of education is very important in building a complete Indonesian human being. This study aims to evaluate the school information system on extracurricular organizational activities at SMAN 16 Gowa. Management of organizational members in schools that previously used manual recording became a web-based computerization. The method used in this research is the System Development Life Cycle (SDLC), which is a classical methodology used to develop, maintain and use information systems. The stages of the System Development Life Cycle (SDLC) are system planning, system analysis, system design, system implementation and operation and maintenance. The results showed that the extracurricular website at SMAN 16 Gowa became a source of extracurricular information, providing information about the number of students participating in extracurricular activities, schedules and extracurricular activities and extracurricular registration media so that students were able to register online without having to register directly. The features it has are the schedule of extracurricular activities, extracurricular achievements, extracurricular galleries and a chat feature with the extracurricular leader. The information system that was built makes it easier to input and is in accordance with the proposed system. Testing and implementation of this system is in accordance with the expected results where the functional input and output systems function properly to replace the manual system that has been used so far
\end{abstract}

Keywords: Extracurricular, Information System, SMAN 16 Gowa, System Development Life Cycle (SDLC)

\section{PENDAHULUAN}

Teknologi digital yang berkembang memiliki dampak yang sangat besar terhadap perubahan perilaku dalam pengelolaan institusi tidak terkecuali di institusi Pendidikan. Pendidikan yang memiliki pengelolaan yang 
baik secara kualitas dan kuantitas berperan penting dalam kehidupan manusia serta membentuk manusia yang berkualitas secara pemikiran atau pemahaman [1]. Salah satu kegiatan yang dapat menunjang dalam bidang pendidikan adalah dengan adanya kegiatan ekstrakurikuler. Siswa yang mengikuti kegiatan ekstrakulikuler dapat memiliki wawasan yang luas, meningkatkan penerapan nilai-nilai pengetahuan dan kemampuan dalam berbagai hal. Kegiatan ekstrakurikuler menjadi tempat menyalurkan dan mengembangkan potensi siswa menjadi keterampilan yang terbentuk setelah melakukan latihan khusus sesuai dengan ekstrakurikuler yang diikuti [2].

Pada umumnya sekolah memiliki sistem informasi ekstrakurikuler. Namun, tidak semua sekolah memiliki informasi ekstrakurikuler yang mengontrol manajemen kegiatan. Dengan memanfaatkan teknologi sistem informasi berbasis website dapat menjadi sebuah revolusi publikasi dalam membuka jangkauan informasi sekolah yang lebih luas lagi untuk menyampaikan berbagai jenis informasi mengenai sekolah tersebut, memberikan kemudahan dalam aktivitas-aktivitas akademik menghilangkan batasan waktu, jarak dan tempat [3]. Penggunaan dan pemanfaatan teknologi digital mampu membawa dampak positif bagi kemudahan pengelolaan kegiatan ekstrakurikuler, seperti dalam hal kecepatan dalam proses pendaftaran anggota (siswa), monitoring absensi kegiatan, pemberian nilai oleh pelatih, semua dilakukan secara digital dengan berlandaskan basis website. Kehilangan data atau kerusakan berkas yang semula berbasis berkas fisik pun mulai digantikan dengan basis data yang terintegrasi dengan aplikasi, sehingga dalam hal pencarian dan pencetakan data menjadi lebih efektif dan efisien [4].

Penggunaan Sistem Informasi Akademik sangat dibutuhkan untuk semua instansi sekolahan. Selain memudahkan dalam dokumentasi, sistem informasi akademik juga mampu mengurangi kinerja waktu dalam memasukkan data yang masih menggunakan cara manual [5]. Pengembangan sistem informasi sering disebut dengan proses pengembangan sistem (system development). Pengembangan sistem dapat didefinisikan sebagai menyusun suatu sistem yang baru untuk menggantikan sistem yang lama secara keseluruhan atau memperbaiki sistem yang telah ada [6]. Banyak metode pengembangan sistem yang tersedia. Salah satu Metode yang paling dikenal disebut juga sebagai System Development Life Cycle atau yang lebih dikenal dengan istilah SDLC. Untuk meningkatkan atau memaksimalkan aplikasi media informasi sekolah yang dibuat, perlu di perhatikan dan dilakukan evaluasi secara berkala terhadap sistem untuk selanjutnya diadakan perbaikan sesuai dengan perubahan dan perkembangan instansi [7]. SDLC adalah proses mengembangkan atau mengubah suatu sistem perangkat lunak dengan menggunakan model-model dan metodologi yang digunakan orang untuk mengembangkan sistem-sistem perangkat lunak sebelumya (berdasarkan best practice atau cara-cara yang sudah teruji baik). SDLC memiliki beberapa Model dalam penerapan tahapan prosesnya antara lain model Sequential Model atau Waterfall, Parallel Model, Iterative Model, Prototyping Model, RAD (Rapid Application Development) Model, Spiral Model, VShaped Model dan Agile Development. [8]

Sejalan dengan perkembangan teknologi, penelitian ini bertujuan untuk mengevaluasi sistem informasi sekolah dalam kegiatan organisasi ekstrakurikuler di SMAN 16 Gowa dalam pengelolaan anggota organisasi di sekolah yang sebelumnya menggunakan pencatatan manual sehingga menjadi komputerisasi. Sistem informasi publikasi kegiatan ekstrakurikuler di SMAN 16 Gowa telah dapat diakses dengan menggunakan jaringan internet. Peneliti menggunakan model SDLC (System Development Life Cycle) yang cocok untuk pengembangan perangkat lunak dan spesifikasi yang tidak berubah-ubah. Dengan menjalankan setiap tahapan yang ada, penelitian bertujuan untuk mengevaluasi sistem informasi yang baik khususnya pada pengelolaan kegiatan ekstrakurikuler SMAN 16 Gowa.

\section{METODE PENELITIAN}

Teknik pengumpulan data dalam penelitian ini dilakukan beberapa tahapan, yaitu observasi dengan melakukan pengamatan langsung terhadap jalannya kegiatan dan pengelolaan ekstrakurikuler pada SMAN 16 Gowa, wawancara terhadap pihak-pihak yang berkaitan dengan tema penelitian, serta tidak terkecuali pengumpulan data dilakukan juga dengan studi kepustakaan yang peneliti ambil melalui buku-buku, literature jurnal yang didapat dari media internet.

System Development Life Cycle (SDLC) adalah metodologi klasik yang digunakan untuk mengembangkan, memelihara dan menggunakan sistem informasi [9]. Siklus hidup sistem itu sendiri merupakan metodologi, tetapi polanya lebih dipengaruhi oleh kebutuhan untuk mengembangkan sistem yang lebih cepat.

Berikut ini merupakan deskripsi dari tahapan-tahapan yang dilakukan pengembangan sistem dengan model SDLC [10]. Perencanaan Sistem merupakan tahap awal dari pengembangan sistem, tahap ini bertujuan untuk mengidentifikasi dan memprioritaskan sistem informasi apa yang akan dikembangkan, sasaran-sasaran yang ingin dicapai, jangka waktu pelaksanaan serta mempertimbangkan dana yang tersedia dan siapa yang melaksanakan.

1. Analisis System adalah penelitian atas sistem yang telah ada dengan tujuan untuk merancang system baru atau memperbaharui system yang sudah ada. 
2. Desain System adalah penentuan proses dan data yang diperlukan oleh system baru. Jika system ini berbasis komputer, rancangan dapat menyertakan spesifikasi jenis peralatan yang akan digunakan.

3. Implementasi System merupakan kegiatan memperoleh dan mengintegrasikan sumber daya fisik dan konseptual yang menghasilkan suatu sistem yang bekerja. Pada tahapan ini dilakukan beberapa hal yaitu: coding, testing, instalasi dan output dari tahapan ini adalah : source code, prosedur dan pelatihan.

4. Operasi \& Pemeliharaan

Tahapan penggunaan terdiri dari 3 langkah yaitu :

a. Menggunakan Sistem

Pemakaian menggunakan sistem untuk mencapai tujuan yang diidentifikasikan pada tahap perancangan.

b. Audit Sistem

Setelah sistem baru mapan, penelitian formal dilakukan untuk menentukan seberapa baik sistem baru ini memenuhi kriteria kinerja. Studi semacam ini disebut dengan penalaraan setelah penerapan dan dapat dilakukan seseorang dari jasa informasi atau oleh seorang auditor internal.

c. Operasi \& Pemeliharaan

Selama manajer menggunakan sistem, berbagai modifikasi dibuat sehingga sistem terus memberikan dukungan yang diperlukan. Modifikasi ini disebut dengan pemeliharaan sistem

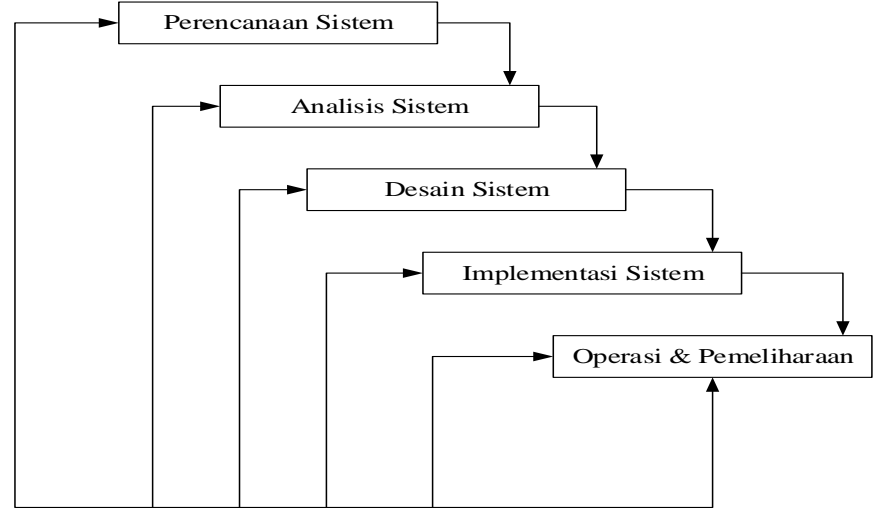

Gambar 1. Pengembangan sistem dengan model SDLC

\section{HASIL DAN PEMBAHASAN}

\subsection{Metode Perancangan Sistem}

Perancangan sistem merupakan mendesain sebuah sistem yang baik dimana isinya adalah langkah-langkah operasi dalam proses pengolahan data dan prosedur untuk mendukung operasi sistem. Fitur-fitur yang dimiliki yaitu jadwal kegiatan ekstrakurikuler, prestasi ekstrakurikuler, galeri ekstrakurikuler dan fitur chat dengan ketua ekstrakurikuler.

\subsubsection{Halaman Login}

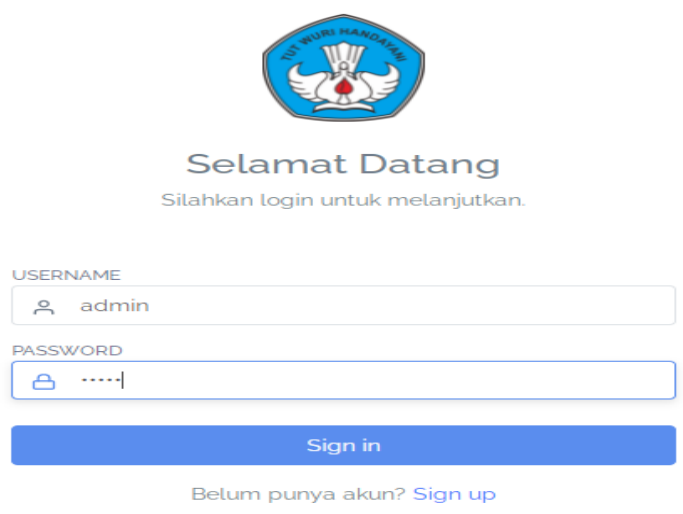

Gambar 2. Halaman Login 
Berdasarkan pada gambar diatas, halaman login pada saat aplikasi pertama kali dijalankan yaitu admin harus memasukan username dan password untuk masuk menu utama agar dapat mengakses menu pada aplikasi. Secara teknis pun saat ini dalam melakukan login bisa juga di gunakan email atau nomor HP pada sistem tersebut. Terdapat juga menu Sign Up yang berfungsi untuk masuk pada menu pendaftaran akun User.

\subsubsection{Halaman Pendaftaran Akun}

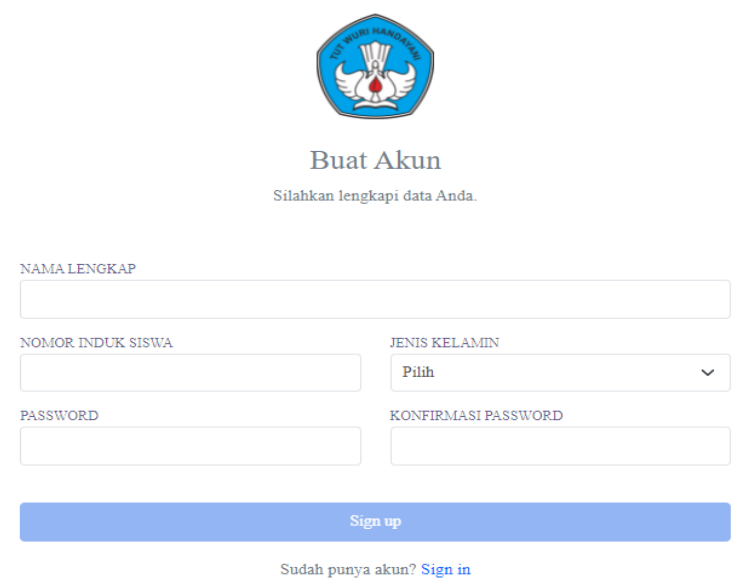

Gambar 3. Halaman Pendaftaran Akun

Pada halaman ini, menampilkan data-data yang akan diinput oleh admin untuk melakukan pendaftaran akun. Data-data user berupa nama lengkap, nomor induk siswa, jenis kelamin, password dan konfirmasi password. Serta terdapat menu sign up yang berfungsi untuk mendaftarkan akun user berdasarkan data yang telah di input.

\subsubsection{Halaman Utama Ekstrakurikuler}

Pada halaman admin terdapat menu dashboard, SMAN 16 Gowa, Kegiatan, Ekstrakurikuler, Prestasi, Galeri dan Data Pengguna. Pada halaman dashboard terdapat informasi mengenai berita atau kegiatan ekstrakurikuler yang terbaru yaitu kegiatan satu minggu ke depan yang akan datang dalam dashboard juga memiliki informasi grafik pendaftar yang mendampilkan total siswa dan total pendaftar ekstrakurikuler. Pada halaman admin juga mampu menambahkan, mengedit maupun menghapus dalam pengelolaan sistem informasi ekstrakurikuler.

\subsubsection{Halaman SMAN 16 Gowa}
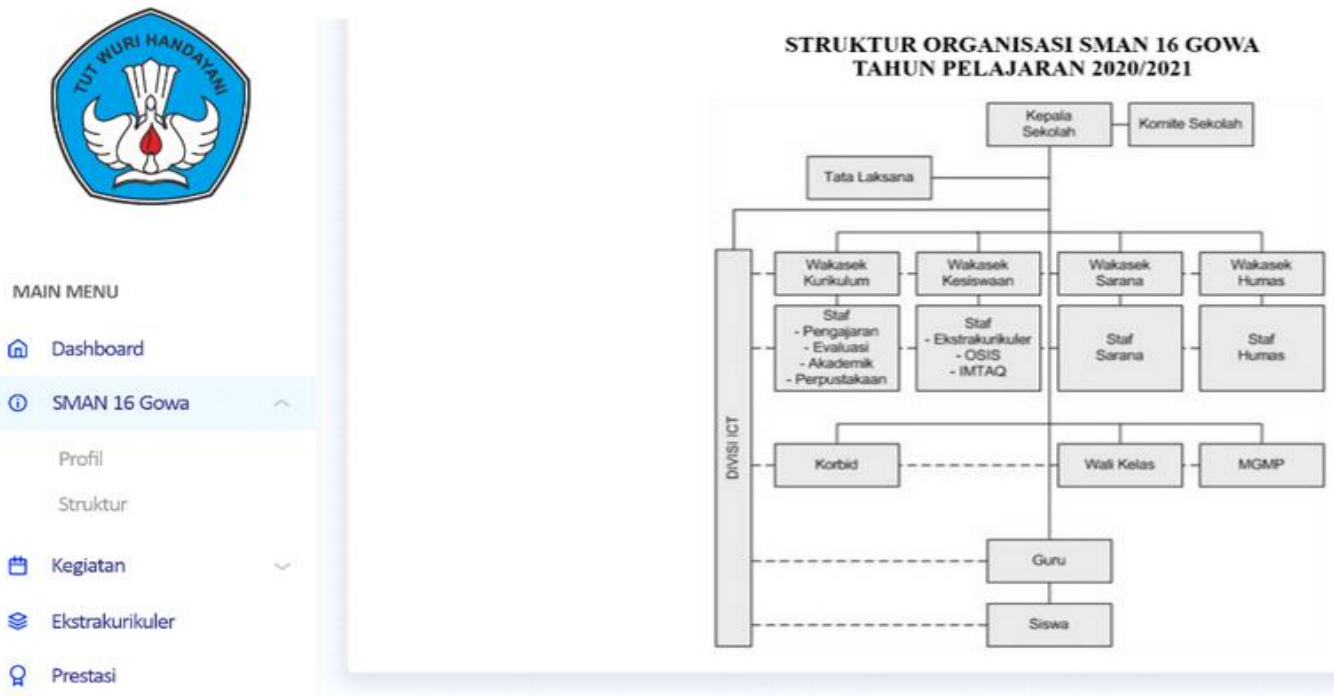

Gambar 4. Halaman SMAN 16 Gowa 
Pada tampilan halaman SMAN 16 Gowa memiliki tambahan menu seperti struktur organisasi dan profil sekolah. Struktur organisasi di SMAN 16 Gowa yang terdiri dari kepala sekolah, komite sekolah, kepala tata usaha, wakasek kesiswaan, wakasek kurikulum, wakasek sarana, wakasek humas, staff, kordinator, wali kelas, MGMP, guru dan murid. Pada menu tampilan Profil yang menjelaskan tentang identitas sekolah yang terdiri dari nama sekolah, status sekolah, status kepemilikan, SK pendirian sekolah, nama kepala sekolah, waktu pembaruan dan visi dan misi sekolah.

\subsubsection{Halaman Kegiatan}

Berdasarkan pada gambar sub menu kegiatan yang memuat data tentang riwayat kegiatan dan jadwal kegiatan.

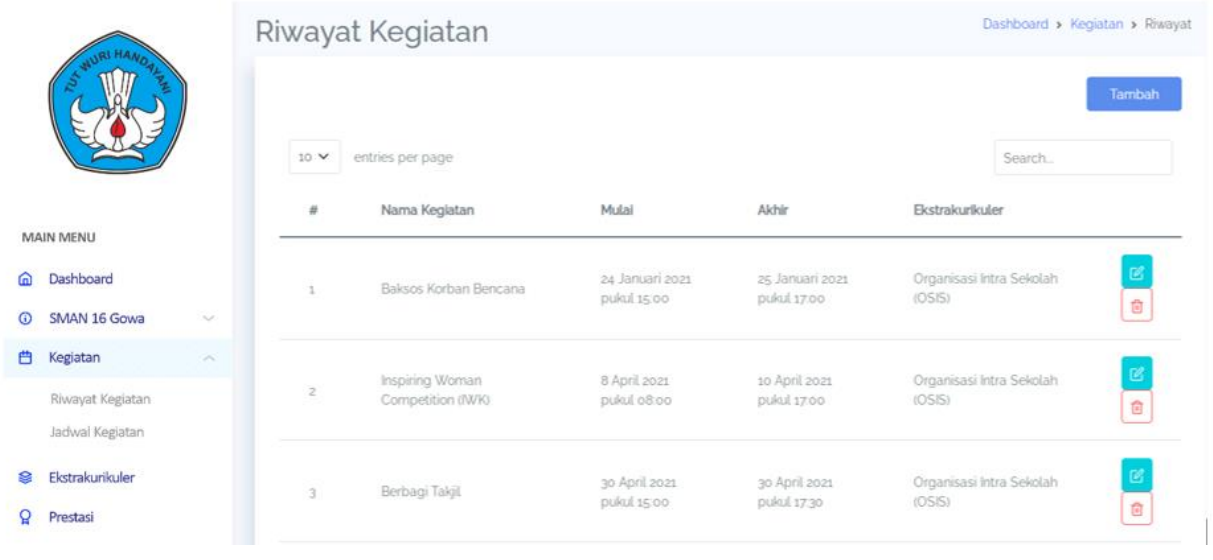

Gambar 5. Halaman Kegiatan

Riwayat kegiatan adalah sesuatu yang telah dilakukan setiap organisasi ekstrakurikuler, pada gambar halaman riwayat kegiatan menampilkan nama kegiatan, jenis ekstrakurikuler mulai waktu kegiatan hingga berakhirnya kegiatan. Jadwal kegiatan adalah program kerja sebelum melakukan kegiatan ekstrakurikuler, halaman kegiatan sama dengan tampilan dari riwayat kegiatan yang membedakan hanyalah bagian pada menu selesai. Ketika admin klik menu selesai bagian jadwal kegiatan otomatis program kerja di jadwal kegiatan langsung pindah kebagian riwayat kegiatan.

\subsubsection{Halaman Admin Ekstrakurikuler}

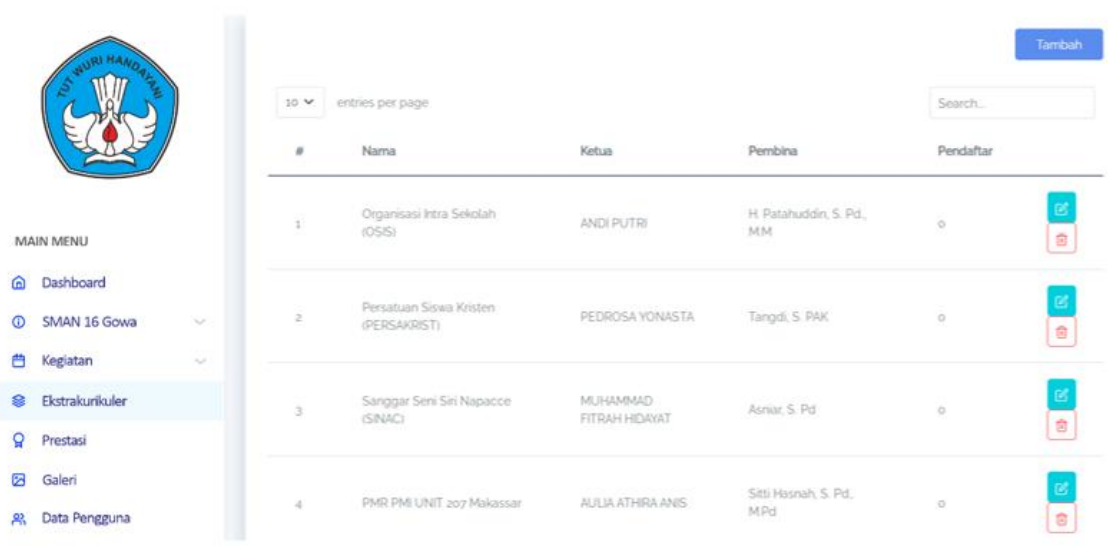

Gambar 6. Halaman Admin Ekstrakurikuler

Pada tampilan halaman admin ekstrakurikuler terdapat menu informasi yang menginformasikan nama ekstrakurikuler, ketua ekstrakurikuler, pembina ekstrakurikuler dan pendaftar ekstrakurikuler. Pada halaman ini admin yang menjadikan setiap ketua ekstrakurikuler berfungsi untuk mengecek atau memeriksa data ketika ada pendaftar yang mendaftar di setiap organisasi ekstrakurikuler tersebut. Setiap ketua dari ekstrakurikuler dia 
hanya berhak memeriksa data pendaftar hanya bagian ekstrakurikulernya saja dan tidak mampu memeriksa pendaftar di bagian ekstrakurikuler lain.

\subsubsection{Halaman Prestasi}

Berdasarkan pada gambar sub menu prestasi yang memuat data tentang prestasi apa saja yang telah dimenangkan ekstrakurikuler di SMAN 16 Gowa

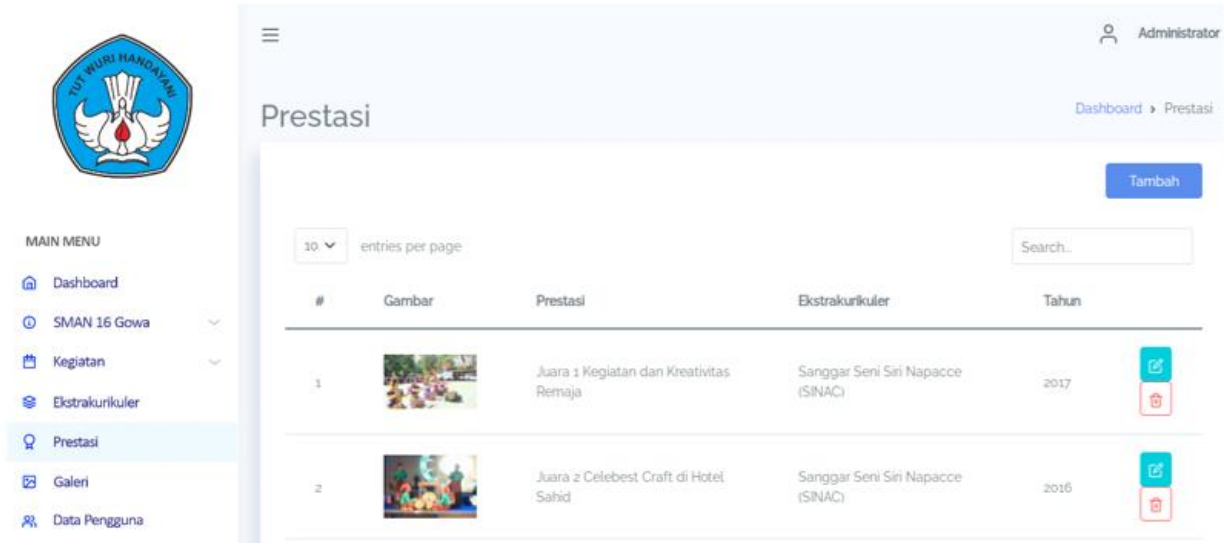

Gambar 7. Halaman Prestasi

Pada tampilan halaman prestasi terdapat menu informasi yang menginformasikan prestasi apa saja yang telah dimenangkan setiap ekstrakurikuler dalam beberapa tahun terakhir. Pada tampilan halaman prestasi terdapat nama prestasi, nama ekstrakurikuler, tahun prestasi dan gambar. Pada halaman prestasi admin maupun setiap ketua ekstrakurikuler dapat menambahkan, mengedit maupun menghapus. Prestasi adalah kebanggan setiap sekolah ketika mampu memenangkan pertandingan/lomba seperti yang dimenangkan SMAN 16 Gowa dalam kategori juara 1 kegiatan remaja dan juara 1 dengan organisasi sanggar seni tari nusantara.

\subsubsection{Halaman Galeri}

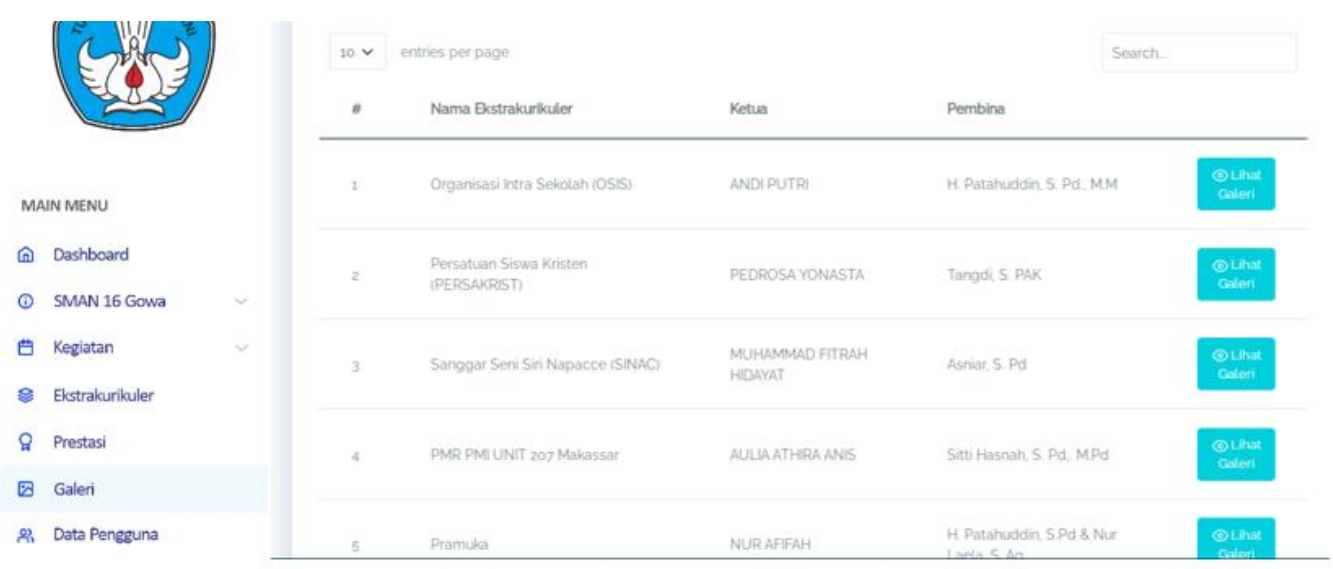

Gambar 8. Halaman Galeri

Pada halaman galeri terdapat menu informasi berupa nama ekstrakurikuler, nama ketua ekstrakurikuler, pembina ekstrakurikuler serta menu untuk melihat galeri ekstrakurikuler. Menu galeri hanya bisa di input oleh setiap ketua ektrakurikuler dan admin. Pada tampilan halaman galeri memliki 11 ekstrakurikuler stiap halaman ekstrakurikuler memiliki galeri yang ingin ditampilkan.

Galeri yang ada dalam website antara lain: Adapun kegiatan ekstrakurikuler tersebut yaitu Pasukan Pengibar Bendera (PASKIBRA), Palang Merah Remaja (PMR), Pramuka, Ikatan Remaja Masjid Al Furqoni (IRMA), Pencinta Alam (PA), Olahraga (Bola Voli, Bola Basket, Karate, Tenis Meja, Tenis Lapangan), Koperasi Sekolah (Kopsis) Dan Patroli Keamanan Sekolah (PKS), Organisasi Intra Sekolah (Osis), Sanggar Seni Nusantara, Dan Persatuan Siswa Kristen. 


\subsubsection{Halaman Pengguna}

Berdasarkan pada gambar halaman yang memuat data tentang pengguna dalam website dapat dilihat pada gambar berikut

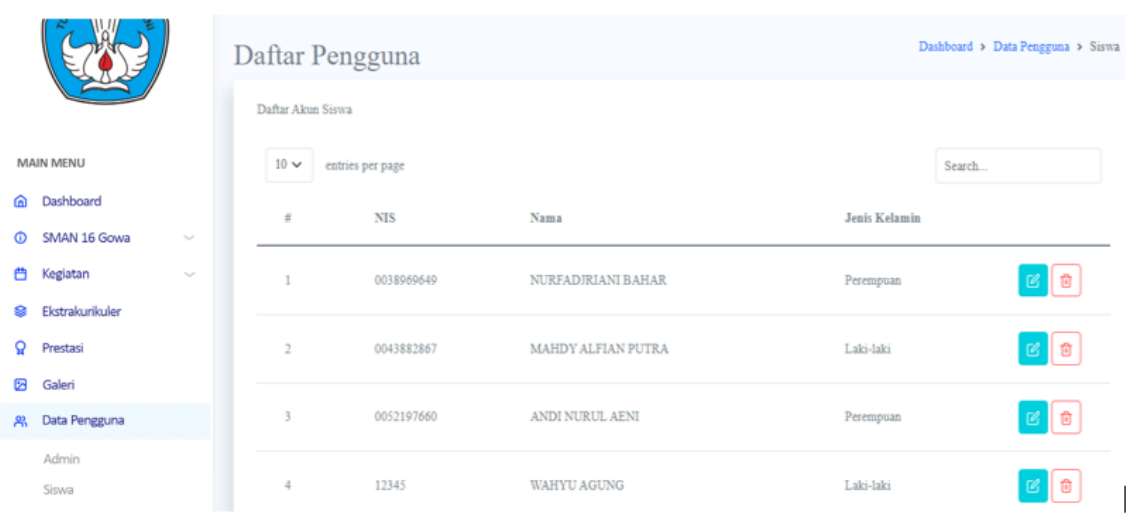

Gambar 9. Halaman Pengguna

Pada tampilan halaman pengguna memiliki tambahan menu seperti admin dan siswa. Admin dalam website ekstrakurikuler SMAN 16 Gowa ini memiliki satu admin penuh untuk mengelolah data-data dalam website pada halaman admin terdapat format tampilan seperti username, nama dan jenis kelamin, admin juga mampu mengedit dan menghapus pengguna dalam katagori siswa. Tampilan halaman siswa adalah jumlah siswa yang telah membuat/mendaftarkan akun. Pada halaman siswa terdapat juga format seperti nis, nama dan jenis kelamin, halaman siswa dalam website ekstrakurikuler ini dia tidak mampu mengedit maupun mengapus siswa atau pengguna siswa yang lain.

\subsubsection{Halaman Pendaftaran Ekstrakurikuler}

Berdasarkan pada gambar sub menu pendaftaran ekstrakurikuler yang memuat data tentang pendaftaran dapat dilihat pada gambar

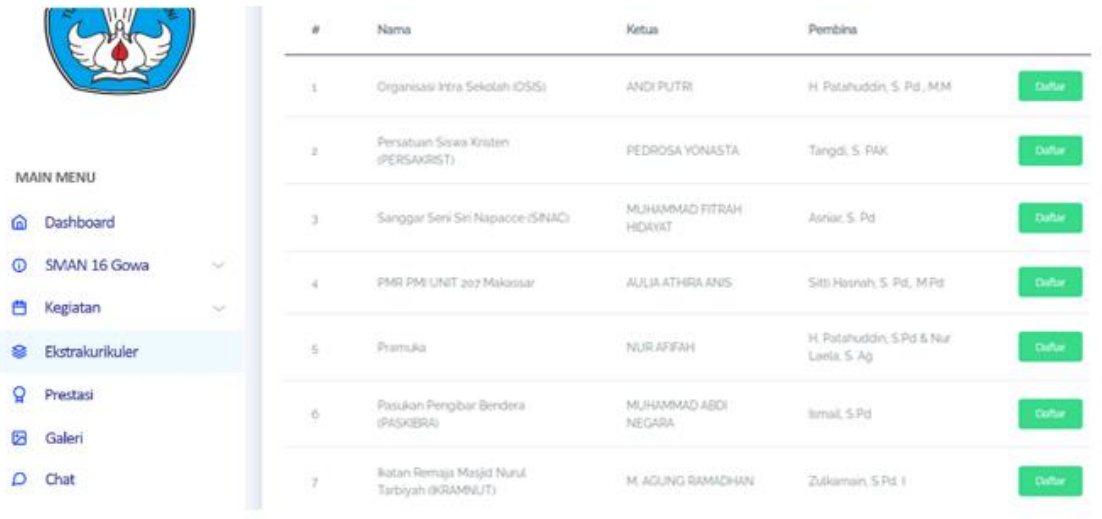

Gambar 10. Halaman Pendaftaran Ekstrakurikuler

Pada halaman pendaftaran ekstrakurikuler menampilkan daftar ekstrakurikuler, nama ketua, pembina ekstrakurikuler serta menu icon daftar. Icon daftar berfungsi untuk masuk pada menu formulir pendaftaran anggota ekstrakurikuler.

\subsubsection{Halaman Pengguna}

Pada halaman formulir ekstrakurikuler ditampilkan formulir yang berisikan data-data yang harus di input oleh pendaftar ekstrakurikuler. Kemudian formulir akan dikonfirmasi oleh ketua ekstrakurikuler melalui akun ekstrakurikuler. 


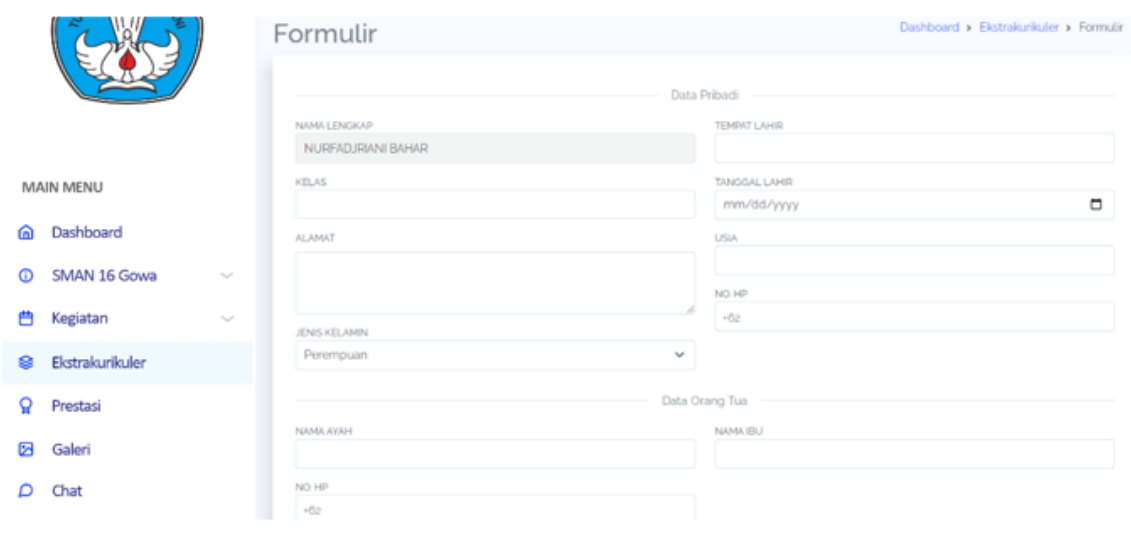

Gambar 11. Halaman Formulir Ekstrakurikuler

\subsubsection{Halaman Pendaftar Ekstrakurikuler}

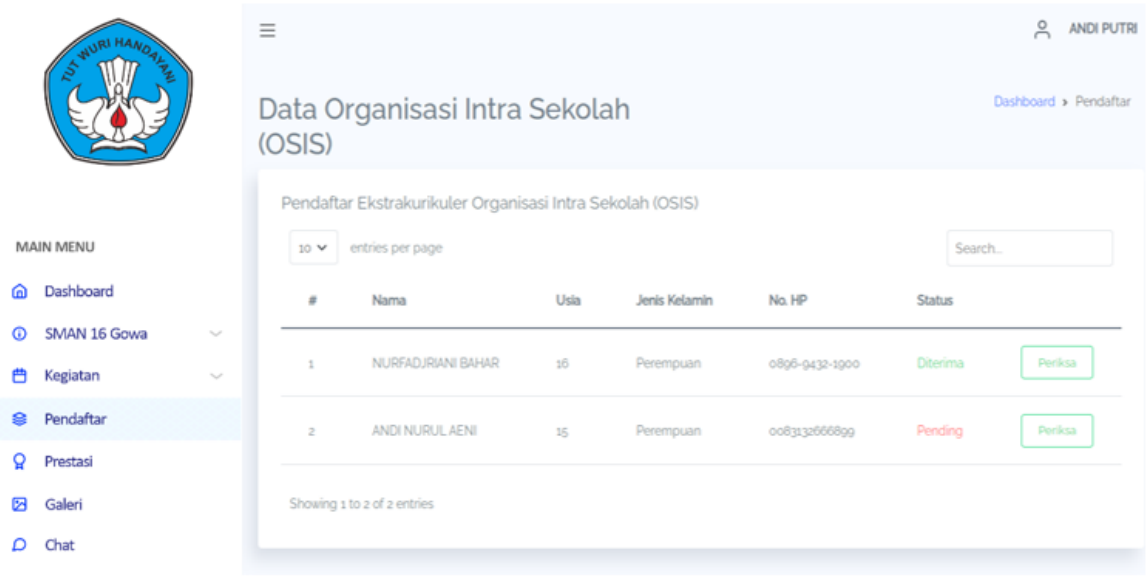

Gambar 12. Halaman Pendaftar Ekstrakurikuler

Pada halaman pendaftar ekstrakurikuler menampilkan daftar siswa yang ingin mendaftar ekstrakurikuler. Data yang ditampilkan berupa nama, usia, jenis kelamin, nomor handphone dan status. Status terdiri atas diterima atau pending. Status diterima merupakan data siswa yang telah diterima data formulirnya sedangkan status pending merupakan data siswa yang belum diterima oleh ketua ekstrakurikuler. Terdapat pula menu periksa yang berfungsi untuk memeriksa data formulir pendaftar ekstrakurikuler.

\subsection{Metode Pengujian Sistem}

Untuk mendapatkan hasil yang maksimal dalam perancangan aplikasi, maka perlu dilakukan pengujian sistem. Pengujian sistem yang dimaksud adalah untuk menguji semua item perangkat lunak yang diteliti dan dibangun sesuai yang ingin dicapai dalam penelitian ini. Pengujian digunakan dalam aplikasi adalah pengujian Black Box. Pengujian Black Box ini adalah pengujian tanpa memperhatikan struktur logika internal perangkat lunak. Pengujian ini digunakan untuk mengetahui apakah aplikasi yang dibangun berfungsi dengan benar dan layak digunakan sesuai yang diharapkan atau tidak.

Pengujian yang dilakukan pada halaman Login untuk admin dan user berisikan username dan password dengan menginputkan code. Jika login berhasil langsung masuk pada halaman utama. Pengujian pada halaman utama admin terdapat menu dashboard, identitas, kegiatan, prestasi, ekstrakurikuler, chat dan galeri. Pada menu identitas terdapat menu tambahan sejarah, visi dan misi, struktur organisasi. Pada dashboard terdapat nomor, nama, email, telepon dan pesan. Jika penginputan berhasil langsung dapat menampilkan sub menu yang diharapkan. Pengujian pada halaman kegiatan untuk insert, update dan delete berita tentang kegiatan apa saja yang ada pada SMAN 16 Gowa. Di halaman ini juga ada nama kegiatan waktu mulai hingga waktu selesai dan juga pada halaman ini kita bisa menambahkan form kegiatan serta mengubah form kegiatan. Pengujian halaman prestasi hanya terdapat tools untuk input, update dan delete tentang prestasi apa saja yang telah dihasilkan 
sekolah dalam beberapa tahun terakhir. Pada tampilan halaman prestasi terdapat nomor, prestasi, tanggal dan foto. Selain itu kita juga bisa menambahkan form prestasi serta mengubah form prestasi. Jika penginputan berhasil langsung dapat menampilkan sub menu yang diharapkan. Pengujian pada halaman ekstrakurikuler hanya input, update dan delete. Tentang apa saja yang ada di sekolah. dan didalamnya terdapat nama ekstrakurikuler, ketua ekstrakurikuler dan pembina ekstrakurikuler. Selain itu pada menu ekstrakurikuler terdapat menu tambahan absensi kehadiran, jadwal kegiatan ekstrakurikuler dan jenis-jenis ekstrakurikuler kemudian di dalam setiap ekstrakurikuler terdapat menu tambahan yaitu pendaftran ekstrakurikuler. Jika penginputan berhasil langsung dapat menampilkan sub menu yang diharapkan. Pengujian berikutnya halaman galeri hanya menunjukkan beberapa foto-foto yang menunjukkan sebuah moment. Contoh foto kegiatan pramuka, PMR, dan futsal yang fotonya dapat langsung di upload. Ada juga button untuk tambah, ubah dan delete. Jika penginputan berhasil langsung dapat menampilkan sub menu yang diharapkan.

\begin{tabular}{ccc} 
& \multicolumn{2}{c}{ Tabel 1. Rencana Pengujian } \\
\hline Kelas Uji & Bagian yang Diuji & Jenis Pengujian \\
\hline \multirow{2}{*}{ Login } & Admin & Black Box \\
& User & Black Box \\
& SMAN 16 Gowa & Black Box \\
& Kegiatan & Black Box \\
Penginputan Data & Ekstrakurikuler & Black Box \\
& Prestasi & Black Box \\
& Galeri & Black Box \\
& Data Pengguna & Black Box
\end{tabular}

\section{KESIMPULAN}

Berdasarkan hasil dari penelitian yang telah dilaksanakan tentang Perancangan Sistem Informasi Ekstrakurikuler Pada SMAN 16 Gowa, dapat disimpulkan bahwa sistem Informasi yang dirancang ini mempermudah dalam penginputan dan sesuai dengan sistem yang diusulkan. Pengujian dan implementasi sistem ini sesuai dengan hasil yang diharapkan dimana fungsional input dan output sistem berfungsi dengan baik untuk menggantikan sistem manual yang selama ini digunakan.

\section{DAFTAR PUSTAKA}

[1] Muhasim, "Pengaruh Teknologi Digital, Terhadap Motivasi Belajar Peserta Didik," J. Stud. Keislam. dan Ilmu Pendidik., vol. 5, no. 2, pp. 53-77, 2017.

[2] A. Mulyani and R. R. M. Fadilah, "Rancang Bangun Sistem Informasi Ekstrakurikuler di Madrasah Aliyah Negeri 1 Garut Berbasis Web,” J. Algoritm., vol. 14, no. 2, pp. 177-186, 2015, doi: 10.33364/algoritma/v.14-2.177.

[3] D. Maharani, "Perancangan Sistem Informasi Akademik Berbasis Web Pada Sekolah Islam Modern Amanah," J. Manaj. Inform. dan Tek. Komput., vol. 2, no. 1, pp. 27-32, 2017, doi: 10.31227/osf.io/r9szc.

[4] M. D. M. N Susila, Badriyah, A. Siregar, "Rancang Bangun Sistem Informasi Website Ekstrakurikuler SMK YAPPIKA Legok Tangerang,” J. Indones. Sos. Teknol., vol. 1, no. 4, pp. 275-284, 2020.

[5] O. D. W. F. Sahrul, M. A. Safi'ie, "Implementasi Sistem Informasi Akademik Berbasis Web Menggunakan Framework Laravel,” J. Transform., vol. 12, no. 1, pp. 46-50, 2016.

[6] A. A. D. Hermandra, "Pengembangan Sistem Informasi Kerja Praktek (Studi Kasus : Jurusan Sistem Informasi UIN SUSKA Riau)," J. Rekayasa dan Manaj. Sist. Inf., vol. 2, no. 1, pp. 11-14, 2016.

[7] A. A. Sofyan et al., "Aplikasi Media Informasi Sekolah Berbasis SMS Gateway Dengan Metode SDLC (System Development Life Cycle)," Angew. Chemie Int. Ed. 6(11), 951-952., vol. 6, no. 2, pp. 1-7, 2016.

[8] Y. Wahyudin and D. N. Rahayu, "Analisis Metode Pengembangan Sistem Informasi Berbasis Website: A Literatur Review," J. Interkom J. Publ. Ilm. Bid. Teknol. Inf. dan Komun., vol. 15, no. 3, pp. 26-40, 2020, doi: Prefix 10.35969 by Crossref.

[9] A. Y. Permana and P. Romadlon, "Perancangan Sistem Informasi Penjualan Perumahan Menggunakan Metode SDLC Pada PT. Mandiri Land Prosperous Berbasis Mobile,” J. Teknol. Pelita Bangsa, vol. 10, no. 2, pp. 153-167, 2019.

[10] A. Wahyudi, "Perancangan Sistem Menggunakan Metode SDLC," J. Din. Inform., vol. 4, no. 2, pp. 1-7, 2018. 